\title{
INSANITY AND ITS TREATMENT IN ISLAMIC SOCIETY ${ }^{1}$
}

\author{
by
}

MICHAEL W. DOLS*

A description of the actual treatment of the insane in medieval Islamic society is a difficult task for three major reasons. First, the medical texts, especially the well-known treatise on insanity by Ishạq ibn 'Imran ${ }^{2}$ give descriptions of various mental disturbances and their therapies; these accounts are, however, usually restricted to the Galenic tradition, are generally nonclinical, and do not emphasize psychoses or florid conditions. Like Islamic law, these accounts are prescriptive rather than descriptive, so that any historical survey of the medical treatment of the insane can rely on them only as supportive evidence or as the rationale for the practice of professional physicians. Second, historical descriptions of disturbed men and women are rare, and one must resort to a wide variety of sources, such as adab (belles-lettres), biographical dictionaries, geographers' and travellers' accounts. These depictions of unusual behaviour are, in fact, evaluative. Thus, the third issue is the serious methodological problem of what is meant by "insanity" or "mental illness". 3 For convenience, insanity may be defined as any behaviour that is judged to be abnormal or extraordinary by a social group at a specific time and place. Within the wide spectrum of human behaviour, members of any society set boundaries to what they believe to be acceptable or permissible. This judgement or consensus depends on the degree to which an individual's behaviour is disturbed as well as on the attitudes of his or her social group toward those actions. ${ }^{4}$ Mental illness is, then, more intimately dependent on social attitudes and beliefs than physical illness, and this social context largely determines the care and treatment of the insane.

* Michael W. Dols, PhD, Wellcome Unit for the History of Medicine, 45-47 Banbury Road, Oxford OX2 6PE.

'This essay was presented at a symposium entitled 'Arabic Science and Medicine, 750-1950', which was held at the Wellcome Institute for the History of Medicine, London, 13-14 December 1984, in co-operation with the League of Arab States. It is an abridgement of my "Majnün": the madman in Islamic society, which will treat more fully the various aspects of the topic. I should like to thank Lawrence Conrad for his helpful comments and suggestions.

${ }^{2}$ Isḥāq ibn 'Imrān, Maqāla fi l-Mālihūliyà (Abhandlung über die Melancholie), and Constantinus Africanus, Libri duo de melancholia, ed. and trans. Karl Garbers, Hamburg, 1977. For other Arabic medical texts on insanity, see below.

${ }^{3}$ See George Mora and J. L. Brand (editors), Psychiatry and its history, Springfield, Ill., C. C Thomas, 1976, especially pp. 172-194.

${ }^{4}$ George Rosen, Madness in society. Chapters in the historical sociology of mental illness, London, Routledge \& Kegan Paul, 1968, p. 90. 
Given these reservations, let us consider an unusually full and interesting passage concerning the insane from al-Maqrizi's chronicle of late-medieval Egypt. ${ }^{5}$ The following account appears unexpectedly among the events of the year 753/1352:

\begin{abstract}
At this time [10 Jumādā II] news arrived from Șafad that, on Friday at the end of Jumādā I, there appeared in the village of $\mathbf{H a t}$ in (in the province of $\mathbf{S a f a d}$ ) an individual who claimed that he was the Sultan Abū Bakr al-Manșür ibn as-Sultān al-Malik an-Nāṣir Muhammad ibn Qalāwun [who had reigned in $741 / 1340] .{ }^{6}$ With him was a group estimated at ten peasants. The news reached the $n \bar{a} ' i b$ [governor] of Safad, and he sent his secretary and chamberlain [to investigate]. They fetched the man, and the $n \bar{a}$ 'ib gathered together the people and the judges. The man claimed that he had been in Qūṣ and that the governor of Qūs had not killed him but had set him free. He had travelled by sea and arrived at Qațā. Since then, he had been in Gaza, and he had there a nurse who had the curved dagger ${ }^{7}$ and insignia of office. The $n a{ }^{\prime} i b$ said: "In those days I was the royal taster [jäshnakir]. I used to make the meals in the morning and evening, and I do not recognize you." The man insisted on his story, and the opinion of some of the people was on his side, for they did not doubt him. The case was clarified by investigation in Gaza, where the woman was found whom he said was his nurse. She confessed that she was his mother and that he had been attacked by madness [junün] for years, usually two or three times a year. The people of Gaza said that he was known as Abũ Bakr ibn ar-Rammāh and that he had a bad reputation and had been beaten frequently with whips. Therefore, the order was given that he be carried out [of the town], and the $n a \bar{\prime} i b$ of Safad put the man's hands and feet into stocks. Subsequently, irons were put on his neck, and he was sent to the sultan [in Cairo]. He arrived at the Citadel on Tuesday the 18th and was questioned in the presence of the amirs. He was confused in his speech and talked irrationally. Then he was brought before the sultan. The man spoke as he wished and spent the night in pleasant conversation [with the sultan] on Thursday the 20th. He became famous in Cairo and Fusțatt. In these circumstances, he spoke as if he were a sultan. He would exclaim: "Pity your sultan; soon I am returning to you." Many people gathered around him, offering him drinks and sweets, and they talked with him. If someone came to him with some water for him to drink, he [the madman] would demand that he [who had offered it] taste it first. ${ }^{8}$ When he saw an amir, he would exclaim: "This is my mamlūk ${ }^{9}$ and the mamlūk of my father." And he would also say: [My fate is] like [that of] my brother an-Nāșir Ahmmad ${ }^{10}$ and my brother al-Kāmil Sha 'bān ${ }^{11}$ and my brother al-Musaffar Hajaji 12 -all of them have been murdered." He stayed in the stocks for two days and was imprisoned on the third. He remained as he was in the prison, and his tongue was cut out.

At this time also someone in Cairo claimed to be a prophet and said that, if he married, the woman would give birth to a son who would proclaim the truth of his prophethood. It was said to him: "What an evil prophet you are!" He replied: "Because you are an evil people!" He was jailed. His case was examined, and it was found that he had left the fools [mamrürin] at the hospital [märistän $]^{13}$ twelve days before. He had been caught repeatedly [after escaping from the hospital]. He is a madman [majnün], so he was put back among the fools.
\end{abstract}

${ }^{5}$ al-Maqrizī, as-Sulük li-ma'rifat duwal al-mulūk, part 2, vol. 3 Cairo, 1958, pp. 865-867.

${ }^{6}$ al-Manșūr Sayf ad-Dīn Abū Bakr, the eldest son of an-Nāṣir, who was exiled to Qūṣ after a successful coup d'etat, was executed there by the governor in that year.

${ }^{3}$ an-Nimjäh; see Dozy, Supplément aux dictionnaires arabes, vol. 2, p. 732.

${ }^{8}$ The intent is that he would not drink the water until the sāqi drank from it, according to the custom of the sultans.

${ }^{9}$ Mamlūks were freedmen whose primary purpose was to form reliable and skilled cavalry regiments: from the ninth century AD, however, the mamlūk corps usurped civil control of most Islamic states and formed a distinct ruling caste in these states. See Daniel Pipes, Slave soldiers and Islam: the genesis of a military system, New Haven, Conn., Yale University Press, 1981; Patricia Crone, Slaves on horses: the evolution of the Islamic policy. Cambridge University Press, 1980; and Michael Dols. The wiack Death in the Middle East, Princeton University Press, 1977, pp. 143148.

${ }_{10}$ Reigned $743 / 1342$, see below.

11 Reigned 746/1345-747/1346.

12 Reigned $747 / 1346-748 / 1347$.

${ }^{13}$ See The encyclopaedia of Islam, 2nd ed., s.v. "Bīmāristān" (Dunlop, Colin, and Sehsuvaroğlu) and note 21 below. Hereinafter referred to as $\mathrm{EI}^{2}$. 
Despite the studies of Professor Muhammad Ziyadah on the prisons in Mamlak, Egypt, we know very little about their organization and functioning, especially with regard to the insane. ${ }^{14}$ Nevertheless, the self-proclaimed sultan appears to have been put in prison because he was believed to be politically dangerous; it is ambiguous from the text whether he was silenced literally or figuratively. The self-proclaimed prophet was eventually returned to the hospital, which was probably the famous Manșari Hospital, founded in Cairo in AD 1284. That this hospital cared for the insane is clear from the evidence of its endowment deed, medieval and modern descriptions, and its architectural plan. ${ }^{15}$

The special provision for the insane is a remarkable aspect of the Islamic hospital. Unlike the earlier Byzantine hospitals, ${ }^{16}$ the Islamic hospitals invariably included wards for men and women who were mentally ill. Why this should be so is a difficult question. ${ }^{17}$ Yet it is probable that the first major hospitals established in Baghdad in the ninth century AD treated the insane. A märistan was certainly founded by Ibn Talan in Egypt in AD 872-73, and it appears to have provided for the insane. ${ }^{18}$ In any case, facilities for the mentally ill became a customary feature of the Islamic hospital. Medieval travellers often noted the provision for the insane; for example, in 578/1183, Ibn Jubayr described the Nașiri Hospital in Cairo in the following way:

A third [building] that adjoins them [the other two buildings of the hospital] is a large place. having rooms with iron windows; it serves as a place of confinement for the insane. They also have persons who daily examine their condition and give them what is fitting for them. All these matters the sultan oversees, examining and questioning. and demanding the greatest care and attention to them. In [Fustațt] there is another hospital of precisely the same model. ${ }^{19}$

Two years later (580/1185), Ibn Jubayr visited Damascus and saw two older hospitals that greatly impressed him. There was also "a system of treatment for confined lunatics, and they are bound in chains." ${ }^{20}$ Following these precedents, hospitals with

\footnotetext{
14 Muhammad Ziyādah, 'as-Sujūn fĩ Miṣr fị l-'uṣūr al-wusṭā’, ath-Thaqạ̄ah, vols. 260, 262, 279, Cairo, 1943-44, pp. 2123-2125, 20-22, 424-426 respectively.

${ }^{15}$ See the survey of this hospital in Ahmad 'İsā (Issa), Histoire des Bimaristans (hôpitaux) à l'époque islamique, Cairo, 1928, pp. 40-76; and Max Herz, 'Die Baugruppe des Sultans Qalāun in Kaire', in Abhandlungen des Hamburgischen Kolonialinstituts, vol. 42, Reihe B, vol. 22, Hamburg, 1919, pp. 34 42. The plan that the French architect Pascal Coste drew in the early nineteenth century is the basis of all later reconstructions of the hospital; the two sets of cells strongly suggest their use for insane males and females-see his Architecture arabe ou monuments du Kaire, Paris, 1839, pl. 15.

${ }^{16}$ See Robert Volk, Gesundheitswesen und Wohltätigkeit im Spiegel der hy:antinischen Klostertypika. (Miscellanea Byzantina Monoacensia, no. 28), Munich, 1983, esp. p. 180f. T. S. Miller, The birth of the hospital in the Byzantine empire, Baltimore, Md., Johns Hopkins University Press, 1985.

${ }^{17}$ See M. W. Dols, 'The origins of the Islamic hospital: myth and reality', forthcoming.

18 al-Kindi, The governors and judges of Egypt . ... ed. E. J. W. Rhuvon Guest, (Gibb Memorial Series, vol. 19), Leiden and London, Brill, 1912, p. $216 \mathrm{f}-$ the last stanza of the poem (1. $5 f$ may be construed as a reference to the insane; al-Maqrīzi, al-Mawā 'iz wal-i tibär hi-dhikr al-khiṭat wal-àthär. Bülāq, 1854, vol. 2, p. 405f; see also M. W. Dols. 'Insanity in Byzantine and Islamic medicine', in Symposium on Bl:zantine Medicine, (Dumbarton Oaks Papers, no. 38), Washington, D.C., 1984, p. 135.

${ }_{19}$ The Travels of Ihn Jubayr, trans. R. J. C. Broadhurst, London, Jonathan Cape, 1952, p. 44.

20 Ibid., p. 296. Ibn Jubayr continues: "Some of them let fall some pleasant witticisms according to what we would hear. One of the drollest I heard was of a man who had taught the Koran. The son of a notable in the town, a youth bearing some traits of beauty called Nasr Allah, was in the habit of reading it to him, and the man became infatuated with the youth. His passion increased until his brain became disordered and he was taken to the hospital, and his sickness and disgrace became notorious. His father used to visit him and
} 


\section{W. Dols}

asylums for the insane were built throughout the Islamic world until modern times. ${ }^{21}$

The development of the early Islamic hospital had coincided with the massive translation of early, primarily Greek, scientific works into Arabic. The translators as well as their translations surely reinforced an orientation to Galenic medicine that was practised by Christian and Jewish doctors in the Hellenistic Near East. Both the hospital and the translations were the direct result of princely patronage that allowed these projects to be carried out on a grand scale. It also allowed medicine to develop as a discipline largely beyond religious constraints. Compared to the transference of Greek scientific knowledge to Rome in antiquity, there appears to have been a conscious effort by the 'Abbasid élite to promote medicine especially, making it accessible to Arabic-speaking practitioners and patients. Thus, an adherence to Galenic principles became the criteria for professional medical status in Islamic society and was closely associated with training in the hospital.

Galenic medicine emphasized the physical causation of illness. ${ }^{22}$ Insanity was a disturbance or dysfunction of the brain, which controlled mental activity and emotions. The functioning of the brain, and the body in general, depended upon the proper mixture of the humours and their qualities, so that the treatment of any illness was aimed at the restoration of the balance of these humours. It may be said that this somatic approach created the concept of "mental illness". The physiological approach was further developed in late antiquity and was directly inherited by Islamic doctors. For example, even passionate love, ish q, was commonly considered by Islamic physicians as a mundane illness. ${ }^{23}$ Whereas madness was interpreted in various ways in antiquity, for Galen, it was an illness like all other illnesses; ${ }^{24}$ logically, madness should come to be treatable, like all other illnesses, in the hospital.

once said to him, 'Go, and get back to the part of the Koran you were at,' and the man, jesting with the boldness of the possessed, replied, 'What part of it have I retained? Nothing of the Koran remains in my memory save "when there comes the Help of Allah" [Qur'ān CX,1].' Men laughed at him and what he said, and we beg of God that he and all Muslims might be forgiven. He remained in this state until he died; may God grant him His forbearance."

${ }^{21}$ See E. Bay, 'Islamische Krankenhäuser im Mittelalter unter besonderer Berücksichtigung der Psychiatrie', Dissert., Medical Faculty, University of Dusseldorf, 1967; A. Terzioğlu, 'Mittelalterliche islamische Krankenhäuser', Ann. Univ. Ankara, 1974, 13: 47-76; idem, 'Das Nureddin-Krankenhaus in Damaskus (gegr. 1154) aus der Epoche der Seldschuken und seine Bedeutung für die Medizin- und Krankenhausgeschichte,' Historia Hospitalium, 1976, 11; 59-75; idem, 'Mittelalterliche islamische Krankenhäuser unter Berücksichtigung der Frage nach den ältesten psychiatrischen Anstalten', Dissert., Faculty of Architecture, Technical University, Berlin, 1968; 'İsā, Histoire des Bimaristans and his revised and enlarged edition of this work, Ta'rikh al-bìmäristänät fi l-isläm, Damascus, 1939; and M. Desruelles and H. Bersot, 'L'assistance aux aliénés chez les arabes du VIIIe au XIle siècle', Ann. méd.-psychol., 1938, 96: 689-709.

22 Helmut Flashar, Melancholia und Melancholiker in den medizinischen Theorien der Antike, Berlin, 1966, p. 107: "Dabei bleibt in Galens Darstellung vieles unberücksichtigt, was in den früheren Abhandlungen über die Melancholie schon enthalten war, vor allem jede Art von Psychotherapie."

${ }^{23}$ Ibn Sìnā, al-Qānūn, Būlāq, 1877, vol. 2, p. 72f. See Stefan Leder, Ibn al-Gauzì und seine Kompilation wider die Leidenschaft. Die Traditionalist in gelehrter Überlieferung und originärer Lehre, Beirut/Wiesbaden, 1984, index, s.v. "cišq"; and Lois A. Giffen, Theory of profane love among the Arahs, New York University Press, 1971.

${ }^{24}$ For the secondary literature, see Bennett Simon, Mind and madness in ancient Greece, Ithaca, N.Y., Cornell University Press, 1978; Rosen, op. cit., note 4 above, ch. 3; Agnes C. Vaughan, Madness in Greek thought and custom, Baltimore, Md., Johns Hopkins University Press, 1919; Gerald C. Moss, 'Mental disorders in antiquity', in D. Brothwell and A. T. Sandison (editors), Diseases in antiquity. Springfield, Ill., C. 
One of the consequences of this strong physiological tradition was that it did not allow for the easy admixture of theology and metaphysics. Despite the widespread belief in jinn or demons as the cause of insanity, Ibn Sina, for example, was highly sceptical of demonology and attributed insanity directly to physical causes. Following the humoral pathology of Galen, the Islamic medical texts give nosologies of mental illnesses. $^{25}$ The major categories were al-manlyă and $d a a^{\prime}$ al-kalb (canine madness), al-mähkhüliyă and al-quțrub (lycanthropy), al-'ishq and often qaräițis/birsäm (phrenitis). ${ }^{26}$ The texts describe their causation, semiology, and treatment. ${ }^{27}$ According to Ibn Sina, al-manlya or bestial madness (junūn), particularly, was a chronic condition caused by burnt yellow bile or black bile reaching the brain. It was characterized by confusion, agitation, ferocity, and unnatural appearances like a predatory animal; it was like phrenitis, but without fever. ${ }^{28}$ The medical texts generally devote considerable attention to the regimen in order to correct the humoral imbalance of the mentally disturbed. ${ }^{29}$ Overall, the medical texts represent a rational, nonmoralistic, and humane point of view. The Islamic asylums are a striking expression of faith in Galen's physiological psychology. ${ }^{30}$

But there is a paradox here. As in the nineteenth century, when the modern discipline of psychiatry grew out of the neurological approach to insanity, the institutionalization of the insane in the Islamic hospital gave rise to justifiable doubts about a strictly somatic interpretation of mental illness and the Dogmatic tradition of Greek medicine in general. ${ }^{31}$ A good example of these doubts occurs in the mid-eleventh-century treatise of Sa'Id ibn Bakhtisha'. He argued persuasively in his Risalah $f t$-t $t i b b$, for the psychic causation of illness-epitomized by passionate love-in addition to the somatic causation. At the beginning of the fourth chapter of his work, Ibn Bakhtisha" called attention to the neglect of the psychic element in illness by the ordinary doctor "who has not entered the bimaristan and has not seen how the staff treats the sick-pacifying the nerves of some and busying the minds of others, diverting their anxieties and entertaining them with song and other things, exciting

C. Thomas, 1967, pp. 709-722; J. L. Heiberg, Geisteskrankheiten im klassischen Altertum, Berlin/Leipzig, 1927; Jackie Pigeaud, La maladie de l'âme, Paris, Les Belles Lettres, 1981; Flashar, op. cit., note 22 above.

25 The presentation of mental illnesses according to symptoms, causes, and therapies appears first in the works of Celsus (see ibid., p. 75); the scheme is developed further in late antiquity and into the Islamic era.

${ }^{26}$ On the terminology for phrenitis, see Manfred Ullmann, Islamic medicine, Edinburgh University Press, 1978, pp. 28-30.

${ }^{27}$ E.g., ar-Rāzì, al-Hāwì al-kabir, Hyderabad, 1955-68, vol. 1, pp. 61-82; aṭ-Ṭabarī, Firdausu l-Hikmat or The paradise of wisdom, ed. M. Z. Siddiqi, Berlin, 1928, pp. 138-149; J. G. Balfour, 'An Arab physician on insanity', J. ment. Sci., 1876, 22: 241-249; Thābit ibn Qurrah, Kitäb adh-Dhakirah, ed. G. Sobhy, Cairo, 1928, ch. 7; al-Majūsī, Kāmil aṣ-ṣinà ah at-tibbìyah, Būlāq, 1877, vol. 1, pp. 332-336; Isḥāq ibn 'Imrān, Maqāla fi l-Mālihüliyà. A brief survey of Islamic medical interpretations of insanity is given in M. W. Dols, 'Insanity in Islamic medicine", in the Proceedings of the International Congress for the History' of Medicine (Cairo, December 1984), [in press].

${ }^{28}$ Ibn Sīnā, al-Qānūn, vol. 2, p. 63.

${ }^{29}$ See especially Isḥāq ibn 'Imrān, Maqāla fi l-Mālihüüliyā, pp. 103a-109a.

${ }^{30}$ See Stanley W. Jackson, 'Galen-On mental disorders', J. Hist. behav. Sci., 1969, 5: 365-384; Luis Garcia Ballester, 'Diseases of the soul (Nosèmata tès Psychès) in Galen: the impossibility of a Galenic psychotherapy', Clio Medica, 1974, 9: 35-43; I. E. Drabkin, 'Remarks on ancient psychopathology', Isis, 1955, 46: 223-234.

${ }^{31}$ See the introductory survey by Andrew Scull in his Madhouses, mad-doctors, and madmen, London, Athlone Press, 1981, pp. 5-32. 
some of them by abuse and scorn and stirring their souls . ..."32

This glimpse of the mental patients in the hospital through the eyes of a prominent doctor leads to the question of the actual treatment of the mentally ill in the medieval period. Most conspicuous in the historical accounts, as in that of Ibn Jubayr, is the frequent mention of the various forms of restraint that were placed on the violently insane. ${ }^{33}$ Good evidence of the institutional care of the insane is furnished by Leo Africanus (AD 1465-c. 1550), who was secretary at the hospital for the insane in Fez for two years. He said that the insane were bound in strong iron chains in the hospital. The walls of their rooms were strengthened with heavy beams of wood and iron. The person who was in charge of feeding them constantly carried a whip, and when he saw an agitated patient, he administered a good thrashing. Sometimes strangers approached these chambers. The insane called out to them and complained how unjustly they were detained and how cruelly they were handled everyday by the officers, although they were cured of their insanity. Having persuaded the passersby to come closer, the insane would greatly abuse them. ${ }^{34}$ Despite the unpleasantness of these conditions of confinement, the asylums were obviously accessible to visitors (see below), and the conditions of the insane appear to have been accepted in the same matter-of-fact way as other disabilities. The asylum is almost a commonplace theme in Arabic literature; for example, a highly entertaining tale in The thousand and one nights about Aba l-Hasan the Eccentric, who was deceived by Haran ar-Rashid into believing that he was the caliph. ${ }^{35}$

The harsh conditions of the asylum should not be misconstrued. The general understanding and treatment of insanity in the Islamic hospital do not fit Michel Foucault's harrowing interpretration of the development of the hospital in seventeenth- and eighteenth-century Europe ${ }^{36}$ The chains and irons in the Islamic hospital were simply necessary devices to prevent harm to the insane or to others; it was not a "great confinement". Despite the apparent cruelty, one can take a benign view. For example, the foreign traveller Jean de Thévenot, who visited Cairo in the

\footnotetext{
${ }^{32}$ Fols. 74r-74v in F. Klein-Franke (ed. and trans.), Über die Heilung der Krankheiten der Seele und des Körpers, in Recherches, nouvelle séries: B. Orient chrétien, vol. 4, Beirut, 1977; and idem, Vorlesungen üher die Medizin im Islam, in Sudhoffs Archiv, Beiheft 23, Wiesbaden, Steiner, 1982, ch. 7.

${ }^{33}$ E.g., The itinerary of Benjamin of Tudela: travels in the Middle Ages (1983 repr.), p. $98 \mathrm{f}$. See also Jacob Seide, 'Medicine and natural history in the itinerary of Rabbi Benjamin of Tudela (1100-1177)', Bull. Hist. Med., 1954, 28: 401-407. Ibn Sīnā (al-Qänün, vol. 2, p. 65) recommended restraint of the insane in a suspended cage; cf. Paulus Aegineta, The seven books, vol. 3, p. 14.

${ }^{34}$ Leo Africanus, The history and description of Africa, trans. Robert Brown, London, Hakluyt Society, 1892, vol. 2, p. 425f; also Description de l'Afrique, ed. and trans. A. Épaulard, Paris, 1956, vol. 1, p. 187. In the Brown translation, Leo Africanus continues: "And having thus persuaded the commersby, approaching neerer and neerer unto them, at length they take hold with one hand on their garments, and (like villans) with the other hand they shamefully defile their faces and apparell with dung. And though all of them haue their priuies and close stooles, yet would they be poysoned in their owne filth, if the seruants did not often wash their lodgings: so that their abominable and stinke is the cause why citizens neuer visit them. Likewise this hospitall hath many roomes for the purneiors, notaries, cookes, and other officers belonging to the sicke persons; who each of them haue some small yeerely stipend. Being a yoong man I myselfe was notarie heere for two yeeres, which office is worth three duckats a moneth."

35 Powys Mathers, (trans.), The hook of the thousand nights and one nights, London, 1972 repr., vol. 3. pp. 230-267; see also vol. 4, pp. 56-82.

${ }^{36}$ Michel Foucault, Madness and civilization, London, Tavistock, 1973. See M. W. Dols, 'Charity and welfare in medieval Islamic society’, forthcoming.
} 


\section{Insanity and its treatment in Islamic society}

mid-seventeenth century, described the Mansari Hospital in the following way: "The Hospital and Mosque of Mad People is very near Han Khalil; [the insane] are chained with heavy iron chains, and [they] are led to the Mosque at prayer time... The Hospital is called Morestan, and it serves also the sick Poor, who are well entertained and look'd after in it."37

Judging by the medieval medical texts, the doctors apparently paid close attention to the patient's regimen; the "non-naturals", 38 especially exercise, a restful environment, and ample sleep, should be studied and adjusted, so that the patient's daily life would be conducive to recovery. Treatment included baths, fomentations (particularly to the head), compresses, bandaging, and massage with various oils. Bloodletting, ${ }^{39}$ leeches, cupping, and cautery also appear to have been used. Medication with both simple and compound drugs, usually of vegetable origin, as well as theriacs, ${ }^{40}$ were given to the mentally ill in every possible form. ${ }^{41}$ The drugs included purgatives, ${ }^{42}$ emetics, digestives, and sedatives, especially opium. ${ }^{43}$ An emphasis on drug therapy may be attributed to Rufus of Ephesus because of his significant influence in this area of Islamic medicine.

The purpose of the diets, baths, and medicines was generally, as Ibn Sina said, ${ }^{44}$ to increase the moisture of the body in opposition to the presumed drying effect of the black bile. Cold and moist foods were also advised by Ișhă ibn 'Imrân as a corrective to the burnt yellow bile, the major cause of mania; whey, particularly, was highly recommended on the authority of Galen. ${ }^{45}$ The purpose of the bloodletting and purgatives was to evacuate the damaging black bile. And the drugs were obviously intended to calm the excited, stimulate the apathetic, and comfort the depressed.

Ibn Abi Ușaybi'ah described such drug therapy at the Nar ad-Din Hospital in Damascus: "In the hall [qa'ah] of the fools [mamrürin] Muhadhdhab ad-Din prescribed

37 The travels of Monsieur de Thevenot into the Levant, London, 1687, part 1, p. 143.

${ }^{38}$ See M. W. Dols, Medieval Islamic medicine. Ibn Riḍuàn's treatise "On the prevention of hodily ills in Egypt", Berkeley, University of California Press, 1984, p. 13ff.

${ }^{39}$ See the remarks of Prosper Alpin, La médecine des Egyptiens, Cairo, Institut Français d'Archéologie Orientale, 1980, vol. 1, p. 142; Ghada Karmi, 'The colonization of traditional Arabic medicine', in Roy Porter (editor), Patients and practitioners. Lay perceptions of medicine in pre-industrial society, Cambridge University Press, 1985 , pp. 320-322.

40 Ibn Iyās relates an interesting aspect of the hospital and theriacs in the context of the Sultan an-Nāșir's (901/1496-903/1498) own derangement: "The sultan desired to see the dissection of serpents that were prepared at the hospital [for theriacs]. The operation was, therefore, made in his presence in the rooms of the Bahra, and he paid great attention to it. He awarded robes of honour on the chief doctor Shams ad-Din Qūsūfi and on his son, as well as on psylle who had procured the serpents, and on other individuals." (Histoire des mamlouks circassiens, trans. Gaston Wiet, Cairo, Institut Français d'Archéologie Orientale [1945], vol. 2, p. 399). For a fuller discussion of this operation, see Gary Leiser and M. W. Dols, 'Evliyā Çelebi's description of medicine in seventeenth-century Egypt', forthcoming.

${ }^{41}$ For a general description of relevant materia medica, see Isḥāq ibn 'Imrān, Maqāla, pp. 109b-120a.

42 See J. Moreau, 'Recherches sur les aliénés en Orient', Ann. méd. psychol., 1843, p. 111.

43 The careful study of hospital formularies may furnish indirect evidence of actual practices in the hospitals. See also Max Meyerhof, 'Über eine arabische Krankenhauspharmakopoë aus Kairo (um $1200 \mathrm{n}$. Chr.)', Max Neuburger Festschrift, Vienna, 1948, pp. 340-345; 'ad-Dustūr al-bìmäristānì, Le formulaire des hôpitaux d'Ibn Abil Bayan, médecin du Bimaristan Annacery au Caire au XIIle siècle', ed. R. P. Paul Sbath, Bulletin de l'Institut d'Égypte, 1932-33, 15: 12-78; C. Pena Munoz and J. Luis Valverde, 'The formulary of the hospitals of Ibn Abi I-Bayan (XIII century)', Proceedings of the First International Conference of Islamic Medicine, Kuwait, 1981, pp. 224-229.

${ }^{44}$ Ibn Sinā, al-Qānūn, vol. 2, pp. 64-65.

45 Isḥaq ibn 'Imrān, Maqàla, p. 109a. 


\title{
M. W. Dols
}

for a man who had been stricken by the illness called maniya, that is the bestial madness [al-junun as-sabu t], an ample amount of opium to be added to the barley water at the time he was given to drink. The man improved and the condition disappeared."46

In this regard, Ibn Abi Ușaybi'ah also related an interesting story about Ibn Hibatallah (d. AD 1154 or 1165), ${ }^{47}$ who cared for the sick at the Adudi Hospital in Baghdad. Although the story may be apocryphal, it presumes that the treatment of the insane and the humoral theory were commonplace in the hospital, and it suggests that the latter strongly influenced everyday therapeutics. One day a woman came to him in the hall of the insane that he supervised and asked him for advice about her son's illness. He responded to her:

\begin{abstract}
"It is desirable that you give him food and drink that is cold and moist." Several maniacs that he treated in the hall mocked him when they heard this, and they said to him: "You may be able to give such a prescription to one of your students who is knowledgeable about the laws and secrets of medicine. As for this poor woman, how can she know the cold and moist things? Prescribe for her instead a definite remedy, so that she knows what it consists of." Far from being irritated by this, the doctor kept an absolute silence. ${ }^{48}$
\end{abstract}

The medical texts also attest to psychotherapeutic techniques that may have been employed. There is clearly a concern in the texts for the personal, educative role of the physician. The psychic healing of the patient's condition can be traced back to antiquity, and anecdotal accounts of the wise physician are often repeated in Islamic garb. In general, however, ancient medicine did not develop a concept of the healing power of words or dialogue. ${ }^{49}$ From late antiquity, however, there seems to have developed a "therapy of the word" or a greater belief in the psychogenic causation of mental illness. ${ }^{50}$ Professor Bürgel has even suggested that the use of shock or shame therapy, specifically, may have originated with Islamic doctors. ${ }^{51}$ In any case, these medieval doctors were apparently sensitive to the psychosomatic aspect of illness, especially some forms of mental disturbance. The treatise of Ibn Bakhtisha' is a fine expression of this sensitivity. We also get hints of such treatment in the general medical texts. For example, ar-Razi sensibly urged the practising doctor to destroy a melancholic's obsession with trifling concerns and to reassure the depressive of his reasonable thoughts. 52

Following the classical medical texts, especially Rufus of Ephesus, other psychic means of healing were recommended. Music was used in the Islamic hospitals down to Ottoman times. ${ }^{53}$ Musical performances were given, for example, at the Mansari

\footnotetext{
${ }^{46}$ Ibn Abì Ușaybi'ah, 'Uyūn al-anbā' fi țabaqāt aț-ațibbä', ed. A Müller, Cairo, 1882, vol. 2, p. 242.

${ }^{47}$ See Manfred Ullmann, Die Medizin im Islam, Leiden and Cologne, Brill, 1970, p. 163f. ${ }^{48}$

48 Ibid., vol. 1, p. 254.

${ }^{49}$ Simon, op. cit., note 24 above, p. 227. Cf. Pedro Lain Entralgo, The therapy of the word in classical antiquity, ed. and trans. L. J. Rather and J. M. Sharp, New Haven, Conn., Yale University Press, 1970. ${ }^{50}$ Flashar, op. cit., note 22 above, pp. 77f, 94f.

51 J. Ch. Bürgel, 'Psychosomatic methods of cures in the Islamic middle ages', Humaniora Islamica, Paris, 1973, 1: 171 .

52 ar-Rāzi, al-Häwì, vol. 1, p. 69.

${ }^{53}$ E.g. Ishạà ibn 'Imrān clearly recommends music and dance in his Maqāla, pp. 102b-103a.
} 


\title{
Insanity and its treatment in Islamic society
}

Hospital in Cairo during the medieval period. ${ }^{54}$ Evilya Celebi visited the Nar ad-Din Hospital in AD 1648, and he reported that concerts were given three times a day. He also noticed that the treatments of the insane were recorded by the chief physician. ${ }^{55}$

From various sources it appears that other forms of diversion were also employed, such as dancing, theatrical performances, and recitations. ${ }^{56}$ Furthermore, Benoit de Maillet, a seventeenth-century Frenchman, recorded that, although most of these features had disappeared at the Manşari Hospital in his time, there still existed the custom of announcing the first prayer of the day two hours earlier than in the other mosques of the city for the benefit of the insomniacs. ${ }^{57}$

There was, moreover, a keen attention to surroundings that would improve the patient's frame of mind. The hospitals, despite the cells for the insane, were usually spacious, monumental structures with fountains and gardens. Remarkable evidence of this aspect of the Islamic asylums is found in Evilya Celebi's description of the mental hospital that was founded in Edirne (Adrianople) by Bayezid II (AD 1481-1512). ${ }^{58}$ To the right of the Bayezid Mosque was an insane asylum, as well as a medical school, in a beautiful garden. The asylum was a massive domed structure; the winter rooms looked out on to the rose garden and inward to the fountain and pool.

\begin{abstract}
Some rooms are heated in the winter according to the nature of the sick; they lay in beds provided with ample blankets and rest themselves on silk pillows, and moan and groan. In the spring, at the time of madness, those from the city who are lovesick and melancholy are put into some of the rooms. Those brought to the asylum by the police are restrained and fettered by gilded and silver chains around their necks. Each one roars and sleeps like a lion in his lair. Some fix their eyes on the pool and fountain and repeat words like a begging derwish. And some doze in the rose garden, grape orchards and fruit orchards ... and sing with the unmelodious voices of the mad.
\end{abstract}

In his very informative report of this hospital, Celebi mentions another type of psychic treatment: in the spring, flowers were dispersed as a type of olfactory therapy, but many of the patients ate the flowers or trampled on them. He mentions that the people of Edirne came to see the senseless, but he does not seem to imply that this visitation was some kind of Turkish Bedlam; rather, it was beneficial for the inmates. Such visits do not seem to have been unusual in Islamic hospitals, judging from the well-known visits of sultans such as Ibn Talan, to their hospitals, and from stories, such as the Three Madmen's Tale in The thousand and one nights and the central episode in the Maqamat of al-HamadhanI. ${ }^{59}$ The most surprising thing to Celebi was the provision by the sultan in the asylum's endowment for three singers and seven musicians who were to visit the hospital three times a week. They played six different

54 Prise d'Avennes, L'art Arabe, Paris, 1887, p. 138.

55 Seyähatnāme, Istanbul, 1971, vol. 13, p. 268.

${ }^{56}$ See the Description d'Égypte, état moderne, Paris, 1809, vol. 2:2, p. $673 \mathrm{f}$.

57 Benoit de Maillet, Description de l'Égypte, ed. Le Mascrier, Paris, 1736, vol. 1, p. 204.

58 J. E. Staehelin, 'Zur Geschichte der Psychiatrie des Islam', Schweiz. med. Woch. 1957, 87: 1152-1153. See also A. Süheyl Ünver, 'Four medical vignettes from Turkey', Int. Rec. Med., 1958, 171: 52-57.

${ }^{59}$ Al-Maqrizi, al-Khitat, vol. 2, p. 405f; Mathers trans., The book of the thousand nights and one nights, vol. 4, pp. 56-82-see Jerome W. Clinton, 'Madness and cure in the 1001 nights', Studia Islamica, 1985, 61: 107-125; The Maqāmāt of Badí al-Zamān al-Hamadhānī, trans. W. J. Prendergast, London, 1973 repr., pp. 100-103; on the latter, see James T. Monroe, 'The Maqāmāt of Badī' az-Zamān al-Hamadhānī and the Picaresque Genre', Papers of the Center for Arab and Middle East Studies, American University of Beirut, 1983, 2: 1-176. 


\section{W. Dols}

melodies, and many of the insane were reported to have been relieved. The inmates were also carefully fed, and two days a week the pharmacy was opened to all the sick of the city who received drugs and potions free.

What has been said about the care of the insane in medieval and early modern Islamic society may be reasonable and informative as far as it goes, but it does not go far enough. This brief survey does not satisfactorily account for the mad sultan and mad prophet in al-Maqrizi's chronicle or the mentally ill outside of the hospital. I would suggest that medieval Islamic medicine was highly pluralistic, encompassing a wide diversity of beliefs and practices, and this pluralism can be seen quite vividly in the case of mental illness. It is worth remembering that insanity is one of the few areas in modern medicine that still retains a pluralistic approach.

Medical pluralism may be said to comprise three ranges or spectra, which may be termed the intellectual, sociological, and somatic (or behavioural), and this model may be applied to mental illness. The first range is a continuum that runs from the strictly naturalistic explanation and treatment of health and sickness to the strictly supernatural. As for the naturalistic, Galenic medicine with its focus in the hospital has already been discussed. The supernatural explanation and practices concerning insanity were very prominent in traditional Islamic society and cannot be ignored. ${ }^{60}$ The jinn were the cause of sickness and disease for many Muslims, and madness (junün) was literally possession by jinn. ${ }^{61}$ The belief in jinn was common in pre-Islamic Arabia and is found in the Qur'an. ${ }^{62}$

The Qur'an and the hadths or pious traditions of the Prophet were the bases of folk psychiatry; this quasi-medical tradition was strongly group-oriented and took a generally benign view of the insane. ${ }^{63}$ Madness was caused by the jinn, the evil eye, or one's failure to observe prescribed rituals and taboos; by physical or emotional trauma; by heredity or simply by God (khilqa). Treatment was an indistinguishable blend of magic and empiricism. Aside from protection from insanity by charms and amulets, cautery (kayy) might be applied to the head or painful part of the body. Madness might be exorcised by a shaykh, in which case special conditions for healing had to be fulfilled. ${ }^{64}$ As early as the thirteenth century in Anatolia, the dervishes performed exorcisms, ${ }^{65}$ and they persisted in the șaft hospices or tekkes of the later

\footnotetext{
${ }^{60}$ See Max Meyerhof, 'Beiträge zum Volksheilglauben der heutigen Ägypter', Der Islam, 1917, 7: 305-344; for Upper Egypt, Palestine, North Africa, etc., see Meyerhof's bibliographical references; Karmi, op. cit., note 39 above, pp. 315-339; and note 63 below.

${ }^{61}$ E.g. Edvard A. Westermarck, Ritual and belief in Morocco, London, Macmillan, 1926, vol. 1, pp. 271. 276, 336, 370.

62 See $E I{ }^{2}$ s.v. "Djinn” (MacDonald, Massé, Boratav, Nizami, and Voorhaeve); Ernst Zbinden, Dic Djinn des Islan unter der altorientalische Geisterglaube, Berne, 1953; Klein-Franke (1982) op.cit., note 32 above, pp. 8-27; Hans Drijvers, 'The persistence of pagan cults and practices in Christian Syria', in East of B!zantium. Syria and Armenia in the formative period, (Dumbarton Oaks Symposium, 1980), Washington, D.C., 1982, p. 38; Karl Opitz, Die Medizin im Koran, Stuttgart, Enke, 1906, p. $22 \mathrm{ff}$.

${ }^{63}$ K. S. Durrany, 'Arab psychiatry', Stud. Hist. Med., September 1980, p. 218f. For the persistence of traditional attitudes and beliefs about insanity in modern Egypt, see Marilyn A. Mayers, "A century of psychiatry: the Egyptian mental hospitals', dissertation, Princeton University, 1984.

${ }^{64}$ See the description of a Muslim exorcist in J. A. Jaussen, 'Le Cheikh Sa'ad ad-Din et les Djinn à Naplouse', Palestine Oriental Soc. J., 1920-24, 1-4: 145-157.

65 Terzioğlu (1974), op. cit., note 21 above, p. 52.
} 


\section{Insanity and its treatment in Islamic society}

Middle Ages. ${ }^{66}$ More recently, the zar ceremony, intended primarily for women, might be used to exorcise evil spirits. ${ }^{67}$

It should be said, however, that Sunni Islam did not promote the doctrine of supernatural healing comparable to Christianity, nor did it possess a clergy empowered to perform exorcisms. Yet, the spread of safism, especially from the eleventh century AD, permitted the resort to saints and saints' tombs for miraculous healing; there was an intimate connection between jinn and the saints' baraka (blessed power). As for the religious minorities in Islamic society, there was a remarkable continuity of supernatural practices. For example, the pre-Islamic Christian practice of incubation in a church, particularly one dedicated to St George, where the violently insane were often bound, lasted in the Middle East from the early Byzantine era until modern times. ${ }^{68}$ Despite our present-day scepticism about such supernatural beliefs and practices, they were widely believed in by people throughout the Mediterranean world during the medieval period, with freemasonry between the three Semitic religions. It may be that folk psychiatry-arising as it does out of native perceptions and experience and answering deeply felt needs-is the most effective of all the forms of native medicine. ${ }^{69}$

The sociological aspect of medical pluralism concerns roughly the continuum of an individual's social status based on wealth, education, family, and so forth. It was often decisive in the care of the mentally disturbed because of their prolonged treatment. The Islamic hospital served primarily the needs of the poor who had no other recourse. Because of the special status of Muslim women, their care in a hospital would seem to indicate the complete inability of families to provide for their supervision. Moreover, one can detect a steady resistance to incarceration of the insane unless the family member was a serious danger to himself or to others. The primary responsibility for the mentally ill in the Middle East had always fallen on the family, and familial medical care persisted until modern times. The Qur'an and Islamic law strongly promote this duty: "Do not give to the incompetent [sufaha] their property that God has assigned to you to manage; provide for them and clothe them out of it; and speak to them honourable words."

The rich were able to pay for expensive drugs, medical care, and nursing or were able to mollify the afflicted if the person were not too disturbed. The author of the famous treatise on melancholy, Ishạq ibn 'Imrân, was called from Baghdad to Qayrawan by the last Aghlabid ruler for treatment of his mental illness. Unfortunately for Ishăq, a rivalry developed between him and another physician that inclined the suspicious, if

\footnotetext{
${ }^{66}$ The treatment of the insane in such a hospice in the modern Sudan is described by John Racy, 'Psychiatry in the Arab East', in L. Carl Brown and Norman Ikzkowitz (editors), Psychological dimensions of Near Eastern studies, Princeton, Darwin Press, 1977, p. 317. For the medical aspects of the tekke in the later Middle Ages, see Leiser and Dols, op. cit., note 40 above.

${ }^{67}$ See John G. Kennedy, 'Nubian Zar ceremonies as psychotherapy’, Human Organization, 1967, 26: 185-194.

${ }^{68}$ See Dols, op. cit., note 18 above, p. 145ff.; The travels of Monsieur de Thévenot, op. cit., note 37 above, part 1, p. 138. For the persistence of monastic healing in Syria until the nineteenth century, see $H$. Katchadourian, 'The historical background of psychiatry in Lebanon', Bull. Hist. Med., 1980, 54: 547f; D. Howell, 'Health rituals at a Lebanese shrine', Middle Eastern Studies, 1970, 6: 181.

${ }^{69}$ Racy, op. cit., note 66 above, p. 317.

${ }^{70}$ Qur’àn 4:4. See A. J. Arberry, (trans.), The Koran interpreted. New York, 1955, vol. 1, p. 100.
} 


\title{
M. W. Dols
}

not paranoid, sultan against Ishạa. Accusations by his colleague led to Ishạa's execution by the unstable ruler. ${ }^{71}$ An example of royal appeasement is the case of an-Nassir Muhammad, the sultan of Egypt from 901/1496 to 903/1498. ${ }^{72}$ The chronicler Ibn Iyas tells us that:

\begin{abstract}
The sultan had a woman whipped in front of him who was then compelled to promenade obscenely on an ass and to wear a yoke on her neck. Such had never been seen before. The sultan presented, moreover, signs of insanity, so that Kurtbāy [the vizier] thought well of keeping him under surveillance by four noble guards. They were charged with preventing him from playing with the children of the people and, in a general manner, preventing him from all initiative. The regent of the king, Tānibak Damalī, slept each night close to him. All these precautions proved useless, for the dissolution of the sultan passed all limits. ${ }^{73}$
\end{abstract}

The account of Ibn Iyas continues with a long, interesting chFonicle of what he considered to be abnormal or unacceptable behaviour by the sultan, reminiscent of the criticism of al-Hakim in the early eleventh century. Ibn Iyas was particularly censorious of the deviance of the sultan in his religious observances, which impaired the diffused dignity of Muslim worship. ${ }^{74}$

The somatic aspect of medical pluralism encompasses the spectrum between an individual's health and illness; regarding insanity, it is a continuum of behaviour between what was deemed normal and abnormal. We can well imagine that most of the modern types of mental illness were present in the medieval period despite culturally determined aspects of symptomatology. ${ }^{75}$ In any case, behaviour could vary from the observably depressed to the highly agitated and enraged, from the harmless madman to the dangerous lunatic. In the latter case, he might be physically or politically dangerous. Aggressive, destructive, or sacrilegious behaviour without a reasonable cause appears to have been the major criterion for judging someone to be insane in medieval Islamic society.

The intersection of these three planes is the point where a decision about medical treatment is made in most illnesses. For mental illness, it is the point where a decision is made on the basis of the behaviour of the afflicted, his background, and his intellectual/spiritual orientation. The symptomatology (in this case behaviour) was crucial but very perplexing. Nevertheless, medieval Islamic society appears to have allowed considerable latitude in the determination of what was normal and abnormal; by tolerating a wide variety of human behaviour, it appears to have accommodated especially the harmless madman and madwoman within the community. ${ }^{76}$ Culturally sanctioned categories of unusual social behaviour included the wise fool and the holy fool, the poet and the lover. ${ }^{77}$

\footnotetext{
${ }^{71}$ Ishạā ibn 'Imrān, Maqāla, xiii-xiv.

${ }^{72}$ See also the accounts of Sultan an-Nāṣir Shihāb ad-Din Ahmad (742/1341-42) in al-Maqrīīi, as-Sulūk, part 2, vol. 3, pp. 593-619, and Ibn Taghrï Birdī, an-Nujüm az-zähira, Cairo, 1929-56, vol. 10, pp. 50-77.

73 Ibn Iyās, Histoire des mamlouks circassiens, vol. 2, p. 378.

${ }^{74} E I^{2}$, s.v. "al-Hākim bi-Amr Allāh" (M. Canard).

${ }^{75}$ See the sensitive treatment of the related subject of hallucinations in Ihsan al-Issa, 'Social and cultural aspects of hallucinations', Psychol. Bull., 1977, 84: 570-587.

${ }^{76}$ This is not to say that Islamic society did not have a normative scheme of behaviour, for normative conduct was expressed by the notion of adab. The concept is discussed, although with an élitist and sūfi emphasis, in Barbara D. Metcalf (editor), Moral conduct and authority, Berkeley, University of California Press, 1984. From an ethical point of view, see Encyclopaedia Iranica, s. v. "Aklāq" (F. Rahman).
} 
The village idiot, the court jester, and the wise fool were tolerated forms of possible derangement. The archetypal wise fool in Islamic literature is Buhlal, the entertaining and harmless critic of social conditions and mores. He typically lurks undisturbed in the cemetery, is molested in the streets by children, or is fettered and put in chains. Having abandoned everyday cares, he trusts in God's aid and men's charity. His intense sensitivity plays on the ambiguity between the unholy and holy fool. ${ }^{78}$

Divine madness is well exemplified by the majdhu $u b^{79}$ or Muslim holy fool, who is quite comparable to the Christian saint. ${ }^{80}$ As the focus of the holy in everyday life, he was free to wander, testing other men's charity if not their sanity. ${ }^{81}$ As a successful prophet, he might even claim to be the expected mahd or messiah. Leo Africanus describes the ordinary majdhüb in sixteenth-century North Africa:

There are certain people in [Tunis] whom a man would take to be distraught, which goe bare-headed and bare-footed, carrying stones about with them, and these are reverenced by the common people, for men of singular holiness. Moreouver on the behalf of one of these mad fellowes, called Sidi el-Dahi; and for the residue of his fond societie, the king of Tunis built one of the aforesaid monasteries, and endowed the same with most ample revenues. ${ }^{82}$

This description can be complemented by many others, both native and foreign. The early ethnographer Edvard Westermarck summarized the matter in the following way:

There is finally a class of holy men and women that is recruited from idiots and
madmen . . harmless lunatics are venerated as saints, whose reason is in heaven while the body is
on earth ... [The majdhüb] is a person who is more or less out of his mind, talkative, often wearing
his hair long (such a person is in Fez called šébšüb), but often clean in habits. He is considered
more holy than the büläli; indeed, of the latter it is sometimes said, . . "A büläli is devoid of God's
mercy." Baraka amounting to sainthood is also ascribed to a person who is said to be
mhälhal . . ., a form of temporary insanity which shows itself in great nervous excitement. This
expression is used of shereefs in cases where an ordinary person would be regarded as mejnün,
mejdüb, or büläli. The saintly lunatic is not held responsible for any absurdity he commits. During
my first stay in Fez there was an insane woman who used to walk about in a state of perfect nudity;
and when I visited the same town again, after an interval of nearly twelve years, she was still alive
and continued her old habit. One of the dead saints of Fez, Sïdi Hammädi, who was mejdüb in his
lifetime, is also known to have walked about in the town quite naked; he is buried in the house
where he lived, and a feast (müsem) in his honour is arranged every autumn by his relatives.

${ }^{77}$ Socrates posited four forms of divine madness, from which our greatest blessings are supposed to come; they are prophetic, telestic, poetic, and amatory. See Simon's discussion, op. cit., note 24 above, pp. 150f, 185f. Promoted by Aristotle, these categories appear in Rufus of Ephesus' work on melancholy, but they died out in late-antique Greek medicine; see Flashar, op. cit., note 22 above, pp. 97, 104. Yet, these non-pathological categories of madness may be said analytically to characterize types of unusual social behaviour that were permitted in Islamic society.

${ }^{78}$ Ulrich Marzolph, Der Weise Narr Buhlül, (Abhandlungen für die Kunde des Morgenlandes), Wiesbaden, Steiner, 1983; an-Nisābūrī, 'Uqlä'al-majānin, ed. W. F. al-Kaylānī, Cairo, 1924; P. Loosen, 'Die weisen Narren des Naisābūrì', Assyriologie, 1912, 27: 184-229.

${ }^{79}$ The delicate ambiguity between mental illness and sanctity seems even greater in the malangs of South Asia; see Katherine Ewing, 'Malangs of the Punjab: intoxication or Adab as the path to God', in Metcalf (editor), op. cit., note 76 above, pp. 357-371.

${ }^{80}$ EI $I^{1}$ s.v. "Madjdhūb" (R. A. Nicholson); EI, ${ }^{2}$ s.v. "Madjdhūb” (R. Gramlich); R. M. Eaton, Sufis of Bijapur, 1300-1700, Princeton University Press, 1978, pp. 243-248, 288f, 295f; Heinrich Schipperges, 'Der Narr und sein Humanum im islamischen Mittelalter', Gesnerus, 1961, 18: 1-12; Alessandro Bausani, 'Note sul "Pazzo Sacro" nell'Islam', Studi e Materiale di Storia delle Religioni, 1958, 29: 93-107; I. Goldziher, Muslim studies, London, Allen \& Unwin, 1971, vol. 2, p. 264.

${ }^{81}$ See Dols, op. cit., note 18 above, n. 7; see also Robert Kirscher, 'The vocation of holiness in late antiquity', Vigiliae Christianae, 1984, 38: 105-124.

${ }^{82}$ Leo Africanus, The history and description, vol. 3, p. 721. 
The growth of safism in the later Middle Ages, with its emphasis on personal mystical experience and ritual, must have enlarged the latitude for unusual behaviour.

Divine inspiration, or creative talent, was an acknowledged attribute of Islamic poets. This kind of madness is nicely demonstrated in Arabic, where majnün (madman) may mean a poet or soothsayer who is inspired by jinn. The Prophet had to defend himself against the imputation by his enemies that he was majnün and that the Qur'an, itself was inspired by jinn. It is unlikely that majnün in the Qur'an, referring to Muhammad, originally meant his insanity, although this was a later interpretation of the term. ${ }^{84}$ According to at-Tabari, Muh ammad is supposed to have feared that he had become either a poet or a person possessed by jinn, but Gabriel assured him that he was a prophet inspired by God. ${ }^{85}$

The passionate lover is a familiar figure in oriental literature. The story of Laylä and Majnün is a classic romance of a man's obsessive love. Denied Layla's hand in marriage, Majnon loses his reason and wanders half-naked, refusing food and living among wild animals. His father takes him on the pilgrimage to Mecca, but his madness only increases. He does, however, have moments of lucidity when he talks of Layla, attempts to regain her, and composes verses about her that he recites to those curious people who have come to see him. Before he dies, he encounters Layla on only one further occasion. The love story was greatly developed in the Persian and Turkish literary traditions, particularly in a mystical direction. Thus Majnan, as a complex literary figure, came to represent vividly most of the forms of "divine madness". 86

Finally, returning to the model of medical pluralism, it is a valuable tool of analysis because it does not suggest a static view of medicine, and with regard to the insane, it can account for the bewildering variety of responses to unusual behaviour. Despite some difficulties with this theoretical construct, it is a helpful framework for understanding a very complex historical phenomenon. There are three distinct advantages to such a paradigm beyond the issue of insanity. It places medicine squarely in its social context as a malleable craft and emphasizes the role of the patient and family, rather than the doctor alone, in the determination of medical treatment. Second, it avoids the mistaken notion that naturalistic medicine was the exclusive preserve of the upper class and, conversely, that the lower class was devoted to magical and religious healing. And third, it emphasizes the continua in the three ranges, especially the intellectual, rather than the customary emphasis on conflict and tensions. I do not mean to deny that such tensions existed between religion and medical science in the Middle Ages. ${ }^{87}$ The paradigm, however, accounts more fully for the eclectic and often contradictory beliefs and practices in the medical and historical texts and, presumably, in the lives of ordinary people.

\footnotetext{
${ }^{83}$ Westermarck, op. cit., note 61 above, vol. 1. pp. 47-49; aside from his bibliographical references, see A.-B. Clot-Bey, Aperø̧u général sur l'Égypte, Paris, 1840, vol. 2, pp. 52 -54; and Moreau, op. cit., note 42 above, pp. 117-119.

${ }^{84} E^{2}{ }^{2}$ s.v. "Madjnūn" (A. T. Welch); W. Montgomery Watt, Bell's introduction to the Qur'ān, Edinburgh, 1970, pp. 77f, 153f; O. M. Oztürk, 'Folk treatment of mental illness in Turkey', in A. Kiev (editor), Magic. faith, and healing: studies in primitive psychiatry today, London, Collier-Macmillan, 1964, p. 349.

${ }_{85}$ Ta'rikh, vol. 1, p. 1150; A. Guillaume (trans.), The life of Muhammad, London, 1955, p. 106.

${ }^{86} \mathrm{EI}^{2}$ ' s.v. 'Madjnün Laylā' (Ch. Pellat, de Bruijn, Flemming, and Haywood); André Miquel and Percy Kemp, Majnün et Laylā: l'amour fou, Paris, 1984.

${ }^{87}$ See Dols, op. cit., note 38 above, p. 40.
} 